\title{
On the impact of the occult on state legitimacy and democratization aid in Africa
}

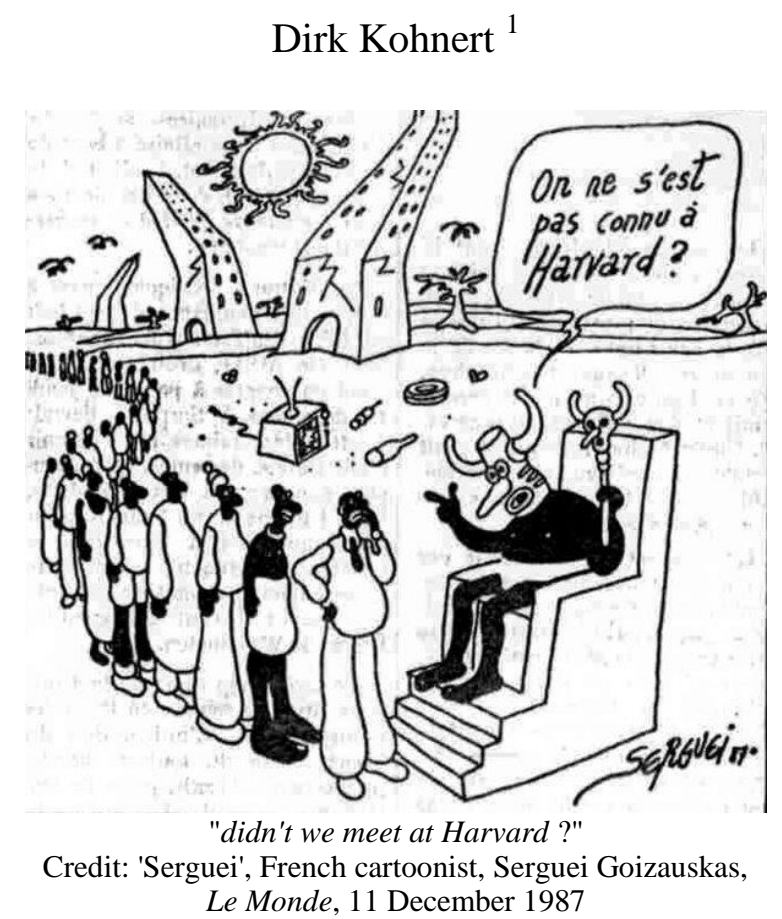

\begin{abstract}
Among politicians and development experts in Africa alike there is a growing awareness of the never decreasing importance of the belief in magic and witchcraft on political decision making since pre-colonial times. Demonstration of the control of occult forces as a means of enhancing legitimacy of traditional or charismatic rule had been considered for over a century to be the prerogative of traditional chiefs and their marabouts; now it proved to be effective for the modern political elite and the state as well. An increasing number of African states officially recognized the existence of magic and witchcraft, and they adapted the imposed colonial law accordingly. In addition magic-religious belief systems, as represented by the vodun or African independent churches (e.g. the Kimbanguists), boasting to control witchcraft, are promoted by African political leaders to enhance legitimacy both of the political class and of state governance. At the same time, development experts tried to take into account the socio cultural dimension of development; they called for an "endogenization" of development aid. This call was justified, because endogenization should be considered as a pre-requisite of sustainable aid; however, under certain conditions it may be ambiguous and dangerous as well. Concerning the consideration of occult belief it may lead to the promotion of illegitimate rule and violation of basic human rights.
\end{abstract}

Keywords: religion, development, democratization, legitimate rule, aid, Sub-Saharan Africa, African Studies, Togo, Nigeria, Zaire

JEL-code: F35, N37, N97, Q17, O29, O35, P48, Z12, Z13

\footnotetext{
${ }^{1}$ Institute of Africa Affairs, GIGA-Hamburg, Germany. A revised version of the text was published as: Kohnert, Dirk: (1997): Zum Einfluß des Okkulten auf staatliche Legitimität und Demokratisierungshilfe in Afrika, Sociologus, 47.1997.1: 24-50.
} 


\section{The sway of occult belief systems on politics and rule in Africa is omnipresent}

In Africa, the belief in people who use supernatural powers for their purposes and exercise harmful magic is not an exotic, socio-cultural marginal phenomenon that is fluffed up by ethnologists who are out of touch with reality. Likewise, the belief in witches is not an extinct relic from pre-colonial times, the relevance of which is now restricted to only a few "backwoods" ethnic groups or regions. Largely independent of religious orientation or level of education, this belief - across all social classes - is still an essential determinant of the thinking and acting of many people, especially in West Africa ${ }^{2}$. For many Africans, witchcraft represents a real existential threat - depending on the circumstances, sometimes latent, sometimes immediate. In their eyes, this threat is less a question of diffuse, impersonal supernatural forces than, rather, very concrete and directly from the potentially omnipresent evil in our fellow human beings themselves ${ }^{3}$ (see Douglas 1970).

Contrary to popular belief of Westerners, so far there are no indicators that belief in magic and witchcraft is waning in the course of the "modernization process" in Africa. Far from it, in the eyes of many Africans, witchcraft has rather increased in frequency and virulence in recent decades. This is attributed, among other things, to a psycho-social response to the "African crisis" in general, and the increasing conflict potential of the ongoing process of social differentiation in Africa due to the "modernization" of economy and society.

Like most religions, occult belief systems try to establish a connection between the known and the unknown. By a reduction of complexity, they try to find a supernatural order in the apparent chaos of the universe. The belief in witches satisfies a deeply rooted human need for confirmation of our own importance, that the world is concerned with ourselves and our destiny and that nothing is left to chance. The justification of misfortune, sickness or death

\footnotetext{
${ }^{2}$ An overview of the status of the international discussion on the topic has been provided already elsewhere (see Kohnert 1996). Only two African sources are cited here: According to the Nigerian religious scientist J. Omosade Awolalu: "no belief (is) more profoundly ingrained than that of the existence of witches ... To the Yorùbá as well as other ethnic groups in Africa, witchcraft is a reality. It is a belief very prevalent among literates and illiterates, among the high and the low in the society. " (Awolalu 1979: 81). An interdisciplinary commission of the government of the Northern Province of South Africa, made up of ethnologists, religious and legal scholars, lawyers and officials, assigned to investigate the witch hunt in the homelands (1987-1994) arrived at the same result: "From the above statements, it becomes very clear that no one can now argue that witchcraft is a myth which can only exist in the minds of the ignorant" ... "The continued frequency of witchcraft murders, if not their increase, deserves special mention. Moreover, belief in witchcraft remains as prevalent as ever. Belief in witchcraft and related practices form part of a basic cultural, traditional and customary principle of Africans in South Africa, and Africa as a whole. " (Ralushai et al 1996: 56-57).

${ }^{3}$ Evans-Pritchards (1937: 8-9) classical distinction between the often inherited, inherent witchcraft or evil psychic power of a person (called 'witchcraft') on the one hand, and the deliberately used harmful magic, the intended use of nature study expert knowledge in connection with magical rites in order to harm others (sorcery) on the other, does not seem to be helpful in this context of problems of witch-hunts in the homelands. This the more so, because Evans-Pritchard's distinction apparently did not apply even in other African societies studies by himself, apart from the Azande (see also Turner 1964; Macfarlane 1970a; Niehaus 1995: 513; Fisiy / Geschiere 1990: 136). - Here and in the following, the belief in witchcraft is understood to refer to a conviction that certain people do use dark occult forces out of illegitimate - usually selfish - motives to harm others. According to an emic conception, witchcraft is in principle "bad", measured by the prevailing legitimacy standards of a society (see Geschiere 1995: 267). For the ambivalence of the transfer of euro-centric pejorative concepts of magic and witchcraft to the African context, see, however, Geschiere (1995: 282) and the literature cited there.
} 
with the 'bewitching' by evil people makes a world bearable, which would otherwise to have to be perceived as deeply hurtful, cold and impersonal (see Nadel 1954: 163-64, 205).

Witchcraft belief has different contents and characteristics, depending on the mode of production in which it is embedded and its socio-cultural and socio-economic framework (see Ardener 1970; Kohnert 1983; Nadel 1952). Therefore, we have to caution against generalizations. Nevertheless, in addition to the facts listed above, there are other established common causes and effects of occult belief in Sub-Saharan Africa. For example, the belief in witchcraft itself (as opposed to the persecution practice) is generally not gender-specific. It is also fully compatible with different educational levels and religions, at least as far as the everyday practice of religion is concerned. Moreover, since pre-colonial times, the Islamic leaders of the northern Nigerian Emirates have instrumentalized the occult belief, that is they used the belief in magic and witchcraft just as well as the leaders of Christian churches as means to subjugate the people. More recently, fundamentalist Pentecostal African churches, mushrooming all over Africa, which integrated the supposedly "primitive pagan" ideas, demonized by the European missionaries, into their conception of the universe (e.g. Pentecostals, Rose Crosses and the Celestial Church of Christ in West Africa), exert a considerable attraction today ${ }^{4}$. Even high Christian dignitaries, such as the Bishop of Kinshasa, believe in witchcraft, a belief that, in their opinion, is shared by $80 \%$ of Africans.

The belief in occult forces has a profound impact on ethics as well as the thinking and acting of Africans. For example, it plays a crucial role in the engagement of conflicting social groups in Sub-Saharan Africa. Its effects are not limited to the private sector or civil society, but the belief also affects the political class and the state apparatus. Occult belief systems are an essential determinant of the decision-making process of African politicians and civil servants at all levels, from the head of state and his government down to the village mayor or the state extension worker. It is obvious that this effect has significant implications for the process of state-building in general and the current process of democratization in Africa in particular.

While since the late 1980 s social scientists have increasingly problematized the political dimension of occult belief systems at the state level (see Geschiere 1996: 83; 1995; Fisiy / Geschiere 1990; Comaroff 1993; Nadel 1954; Niehaus 1993; Schatz $\neg$ berg 1993), development experts and politicians from the donor countries who advise African governments on the implementation of the democratization process, with few exceptions, have so far not even taken note of the problem of the intertwining of occult belief systems, rule and state legitimacy. The much-heralded integration of the "socio-cultural dimension" of development cooperation into policy advice of donors in Africa remains superficial, however, when this essential aspect of African culture is dismissed as an "exotic marginalia".

The following article concentrates on the clarification of the general connection between legitimate rule and occult power as well as on questions of the influence of witchcraft belief on state legitimacy and its anchoring in socio-culturally adapted legal systems of the state.

The underlying experience for the following analyses is provided by field research on the social, economic and political effects of witchcraft in Northern Nigeria, Guinea-Bissau and Bénin (see Kohnert 1983; 1988), as well as experience as an election observer in Africa. Comparative secondary analyses of published case studies on the subject both from SubSaharan Africa and the Caribbean (e.g. vodun in Haiti), as well as a comprehensive analysis

\footnotetext{
${ }^{4}$ s. e.g. Meyer, B. 1992 on the fight of the pentecostal groups against adzetwo (witches) in Southeast Ghana
} 
of the current status of the international discussion on the topic round off the study (see Kohnert 1996).

\section{The belief in witchcraft is a pillar of different forms of legitimate rule}

The process of state-building and democratization are inextricably linked to questions of the legitimacy of the state and its political leaders. Previous experience with election observation in Africa since 1989, i.e. the beginning of the second phase of democratization, shows that fair and free elections based on an open multi-party system can make a significant contribution to improving state legitimacy (see also Engel et al 1995: 2-9,26 -29,178-86). The same experience shows, however, that bogus or facade elections are used by undemocratic regimes and autocrats to blind their voters and to pretend to have a (false) legitimacy of legal rule at home and abroad. The presidential elections in the Gambia (September 1996) or the presidential and parliamentary elections under the Eyadéma regime of Togo $(1993,1994 / 96)$ are notorious examples.

In the eyes of the people concerned, true legitimacy of the state and its political leaders is not created, consolidated or documented solely or mainly through formal democratization and elections. At least in the African context, political legitimacy has several sources. Under the inadequate political, economic and social conditions of an African 'command state' [Kommandostaat, in German, see Bierschenk, Elwert, Kohnert, 1993], and in the face of a patronage system, i.e. Neopatrimonialism firmly anchored in many African countries, political legitimacy is a necessary, but by no means sufficient, a precondition for any sustainable grass-roots democratization (see Schatzberg 1993: 458; Geschiere 1996; Engel et al 1995: 1-28).

In the opinion of the majority of the population concerned, this legitimacy is not so much determined by formal political framework conditions (e.g. political stability; multi-party system; elections) but rather employing traditional socio-cultural structures and worldviews. Both are by no means static but are subject to permanent change (see Geschiere 1995; Kohnert 1983). An integral part of these structures that create legitimacy are occult belief systems in Sub-Saharan Africa, which have been, and still are, essential pillars of the legitimacy of traditional political and religious rulers such as the Emirs and Obas of Nigeria since pre-colonial times.

According to the traditional beliefs shared by many - probably most - Africans today, occult, "supernatural" power can be as real and direct as profane power. Harmful magic or the misdeeds of witches are just as sensible for many Africans, and rationally verifiable, as the punishment by the state judiciary. But even to Western social scientists occult belief systems are anything but "irrational" (see Evans-Pritchard 1937: 330; Gluckman 1944). Though its empirical justification is hardly compatible with categories of scientifically shaped thinking. But the methodological structure of witchcraft-belief is just as rational as that of the ethical guidelines for directing our actions of the Protestant spirit of capitalism, it only follows different rationality. Precisely because occult power does not differ significantly from the emic perspective of the Africans concerned in terms of its reality and in the rationally predictable use of worldly power, every government in Africa that does not want to rely on brute force must prove itself in both spheres of power if it is to be considered effective and legitimate by its citizens. 
Witch-accusations and occult power are usually related to certain people. For this very reason alone, African rulers and their marabouts, for example, both of whom boast to possess magical power, must personally prove it time and again, otherwise, they will be denied ruling capacity. Therefore, it would be only reasonable to assume that only those types of legitimate rule are supported by occult belief systems that are essentially person-related, such as charismatic and traditional rule in the sense of the rule-typology of Max Weber (1972: 12530). Magic and belief in witches would thus to be considered their natural allies. However, everywhere in Africa, we find examples that the attribution of witchcraft applies not only to "traditional rulers" but also to the new political class of modern political leaders who took over the state business after independence. Quite often these leaders have been educated at western elite schools and training grounds such as the French ENA. Almost all African heads of state - not only the old political guard, like Houphouët-Boigny, Bongo, Eyadéma, Kérékou, Nkrumah, Mobutu - but also the new politico-technocrats, couldn't help but to use this recourse to occult belief systems when the opportunity arose. One noteworthy example is Bénin's former President Nicéphore Soglo, who replaced dictator Mathieu Kérékou in the country's first multiparty presidential election 1991.

For calculated, purpose orientation systems of rule, based on the belief in established rules and statutes, the recourse to witchcraft belief as a source of legitimacy would be superfluous. This would apply especially for the modern constitutional state, as propagated by the international donor community as part of the political conditioning of development aid. In such a state, politicians and civil servants should make decisions irrespectively of a person and its social status. Legal rule in the sense of Max Weber (1972: 125-30), based on the recognition of rule-based assignment of performance obligations, authority and means of coercion, rather than on the recognition of persons, would thus be from the yoke of witchcraft-belief. Unfortunately, this is an illusion. It is a deception, not only because in reality the ideological delimitation of rule in this pure form never occurs, and traditional, charismatic and legal rule in today's African countries are rather inseparable.

In fact, in the African context, legal rule must take magic and witchcraft into account if it wants to ensure its legitimacy in the eyes of the population, and this much more often and more intensively than Western scientists, development experts and politicians have assumed up to now: The struggle for the control of witchcraft and occult powers is, from the point of view of many Africans one of the core problems of political rule in countries as diverse as Bénin, Côte d'Ivoire, Nigeria, Cameroon, Zaïre or even in the north of South Africa (see Fisiy / Geschiere 1990: 148 for Cameroon). The effective proof of this control of the occult not only ensures the personal legitimacy of political leaders or traditional authorities. To the extent that state laws and jurisprudence can effectively keep the spread of witchcraft in check in the eyes of the citizens, they also promote the legitimacy of state administrative acts, and thus the state-building process itself.

\section{Gaining legitimacy by socio-cultural adaptation to the occult}

\subsection{Limits of the search for legitimacy using socio-cultural adaptation of the legal system}

The European colonial powers had branded magic and witchcraft as "primitive philosophy" and "backward practices" in their African colonies for more than half a century. Witch accusations were effectively banished, at least from the state jurisprudence, in that colonial 
legislation made both the accusation and the practice of witchcraft a criminal offence (see Nadel 1954: 163-64; Kohnert 1983: 18- 19; Ralushai et al 1996: 57). The colonial masters enforced this prohibition not only for ideological reasons but also for tangible political selfinterest: They feared competing power-centers supported by anti-witchcraft movements, political instability and financial losses for the colonial treasury (see case example of the suppression of the anti-witchcraft cult in Northern Nigeria; Nadel 1954: 196-97; Kohnert 1983: 38, 40).

In regions where witchcraft accusations were particularly widespread, such as in Nupeland, northern Nigeria, the British also forbade secret cults and ordeals, thus prohibiting local 'white' or good witches from fighting evil witches in the view of the concerned. The Nupe now felt completely exposed to the machinations of the witches and feared their uninhibited spread. The ostentatious disregard for deeply-felt fears of the population due to the legal rule of the colonial state based on European legislation (e.g. the Code Napoléon in francophone Africa) contributed significantly to its lack of legitimacy. It led to a deep distrust of the population towards state institutions in general and the evasion from state jurisprudence of "the whites" in particular (see Nadel 1954: 163-4; Raynal, 1994: 300).

After independence - increasingly since the beginning of the 1970s - African politicians and lawyers tried to overcome this obstacle to legitimacy with increasing success. In many countries of Sub-Sahara Africa there was a more or less open re-institutionalization of the crime of witchcraft in local, "traditional" as well as in central state law, as far as the traditional (customary) courts had not already kept their practice of witch-trials anyway, as for example in Northern Nigeria or South Africa (see Ralushai et al 1996: 51). Using the example of Cameroon, Fisiy and Geschiere $(1990 ; 1991)$ have elucidated this process. Additional case studies from Zimbabwe (Chavunduka 1980) and Zaïre (Duvieusart 1992) are available.

In those countries in which the legal dualism, derived from colonial rule, between local "customary" jurisprudence and (central) state judicial violence was at least practically maintained. This adjustment was to take account of "the public feeling" and the needs of the rulers and was most likely most practised there. In Northern Nigeria, where even today $80 \%$ of all court cases are decided by local courts that are bound to the state only formally, but in reality, continue to be committed to the semi-feudal Islamic system of rule (habitually labelled "area-" or "alkali-"courts) "). In South Africa too there are strong indications for legal dualism concerning witchcraft accusations (see Kohnert 1983: 19-25 :; Odinkalu 1992; Ralushai et al 1996: 51-57; see also the case studies by Raynal 1994 for the ZAR).

Rouveroy van Nieuwaal (1990: 143-47) reports from the Mango region in northern Togo that up to the late 1960s practically no state court dealt with witchcraft-charges, while at least $9 \%$ of the local authorities' judgments (l'autorité coutumière) did so. In contrast to the judges obliged to the (colonial) state law, the traditional chiefs did not hesitate to recognize the existence of witchcraft. They even boasted to have occult powers themselves that enabled them to uncover witches. Witches found guilty were killed only in extreme cases. Most of the time they had to pay a penalty or they were obliged to forced labour, e.g. in the fields of the judge and traditional chief until they had atoned for their guilt and were considered cured. In a case study of a chef supérieur from N'zara (North Togo, 1969-71) investigated by Nieuwaal, at least ten women sentenced as witches worked as forced labourers in the fields of the chief. In 1978 Togo officially abolished legal dualism between colonial and common law as one of the last African countries. However, whether this abolition actually took effect or whether it was only a fiction maintained for political reasons, like in Northern Nigeria, South Africa or the ZAR, is open to question. At least the Togolese state-recognized witchcraft implicitly as a 
crime two years later (1980) in the course of a change in the criminal law (Nieuwaal 1990: 152). This recognition was probably related to the "authenticity" campaign propagated at the time in particular by despotic African regimes, such as Zaïre's Mobutu or Togo's Eyadéma regime, in order to strengthen their own legitimacy (see Raynal 1994: 306) and to enable politically instrumentalized witch-hunts, to be discussed later in Chapter 5.

It is therefore not surprising that in a state like Nigeria a legal scientist from the respected Ahmadu Bello University, Zaria, could publicly demand in publications that Nigerian laws and courts revise their negative attitude towards witchcraft accusations ( see Chukkol 1981: 30-36). It is only logical if, from the same perspective, that Ivorian judges seriously recommended the initiation of judges into the art of witchcraft in 1993 in order to be able to better recognize witchcraft from within (s. Kohnert 1996: 1352 ).

But even among some western-oriented legal experts and advisers to African governments, the demand for a move away from euro-centred legal norms towards the recognition of African common law, including the right to self-defence against attacks by witches, seems to find an attentive ear. Thus Rouveroy van Nieuwaal (1990: 157), referring to Renteln (1987), indicated that, for example, sanctioning witchcraft based on the right to self-defence was legitimate. Although judges trained in Western legal perception would feel uncomfortable with such a point of view, it could have even worse social and political consequences (e.g. erosion of legitimacy by the ruling government or political instability) if one wanted to force social change through imposed laws that would be diametrically opposed to the traditional worldviews of the societies concerned.

The current South African government also seems to assume an analogous justification. It apparently wants to combat the witch-craze in the northern province (the former homelands

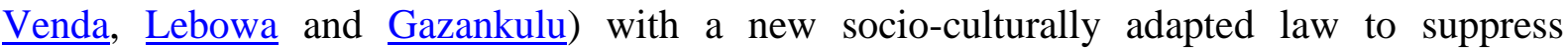
witchcraft, because this witch-hunt has been going on for years and hundreds of women fall victim every year (see also Evans 1992; Minnaar et al 1991; Niehaus 1993; 1995; and Chapter 4). The new bill, the content of which had been supported also by church representatives (e.g. the Zionist Church, ZCC, which is influential in the north), should at the same time prevent the violent riots against supposed witches and take account of the felt-needs of the population and respect their convictions. The South African government's draft law states that "belief in witchcraft and related practices are part of the culture of Africans in South Africa" (Ralushai et al 1996: 59) ${ }^{5}$. The government was largely guided by the experience of neighbouring Zimbabwe, which was specially studied for this purpose and whose supposedly proven legal regulations for the control of witchcraft and witch-doctors or traditional healers were largely adopted (see Ralushai et al 1996: 64). Among other things, through systematic integration of the more than 200,000 miracle healers of the Northern Province into professional associations and a code of honour for this profession. The tendencies pursued in this respect to "domesticate" personal violence (see also Fisy / Geschiere 1994) and the tendency towards

\footnotetext{
${ }^{5}$ See footnote 3. - The above Witchcraft Investigation Commission, which elaborated this draft law, took the view: "The Provincial Government ... grabbed the bull by its horns at a stage when it had already gone wild due to the previous government's neglect in handling witchcraft violence and ritual murders. Far too long, witchcraft beliefs and ritual killings had been wrongly interpreted as a 'practice of primitive people' which, through the eurocentric legal machinery would eventually be abandoned. This approach has proved to be a disaster. " (Ralushai et al 1996: i). - Representatives of a commission of inquiry specifically set up by the South African Zionist Council of Churches (ZCC) on the problem of witch-hunt in the northern province also expressed the view to the government in October 1995: "... that the restoration of the old African order could perhaps help to minimize witchcraft-related violence. " (see Ralushai et al 1996: 59).
} 
monopolizing violence in the hands of the state are unmistakable. They seem to be reasonable and justifiable from both humanitarian and civic theoretical points of view (see Elias 1976).

However, the political intentions and legal opinions on which this demand for the reinstitutionalization of "tried-and-tested old customs" are manoeuvring in contaminated terrain: firstly, such reasoning can only too easily relapse into cultural and legal relativism, which denies the universal validity of fundamental human rights, as claimed by the United Nations and the OAU's African Charter on Human and Peoples Rights (Banjul 1981). This becomes visible in the legal realm for example in the doctrine of "cultural defence", i.e. the right to defence on the basis of one's own cultural heritage. Its introduction in a slightly modified form was also supported by Rouveroy van Nieuwaal, using the example of Togo (see Nieuwaal 1990: 155-57). This opens the door to abuse by the ruler, who tries to sell his particular interests as common interest based on "popular opinion" and (invented) "tradition" (see Chapter 5). Another, better-known negative example of the socio-cultural or political adaptation of legal norms, is the misuse of the Banjul Charter, which was already laid out in its conception. Practically all of the universal fundamental rights mentioned there (e.g. Art. 611) are devalued by excessive reference to restrictive national implementation laws and the back door of "state reason" (see Welch 1992; Wonyu 1992: 35-36). Thus, the Charter's human rights guarantees are perforated like a piece of Swiss cheese. Autocratic regimes, such as the Nigerian military dictatorship, are only too happy to rely on "common law" or "overarching state goals" in order to massively curtail basic human rights by implementing laws and decrees.

Certainly, laws and punishment are not the best way to steer social change in the desired direction. On the other hand, the adaptation of the legal system to the socio-cultural framework of a country shouldn't result in legitimizing oppression, exploitation and a regime of injustice (see Raynal, 1994: 307). Socio-culturally adapted laws and ordinances, combined with a correspondingly adapted juridical system, can be more easily exploited and instrumentalized by changing political alliances or particular political interests, even if they correspond to the legal perception of the population than the previous colonial and eurocentric legal norms, e.g. because the social entrenchment of the former is even less intersubjectively comprehensible.

Therefore, "socio-cultural adaptation" in the field of legislation and law, be it as a means of establishing legitimacy, to secure internal peace or as a development measure to promote the rule of law, should only be used in a very limited manner and with extreme care, if at all. Well-intentioned targets, especially in the realm of the occult, such as the South African draft law cited above, could result in exactly the opposite of the originally envisaged goals if applied within the framework of the African command-state. The consequences of a socioculturally "adapted" exaggerated legal relativism have been revealed by the example of Togo, where - as will be shown in chapter four - the recognition of witchcraft in the Togolese legal system effectively stabilizes the contemptuous injustice dictatorship of the Eyadéma clan.

That being said, even attempting to channel witchcraft belief by the state could, under certain circumstances, promote the witch craze even more rather than curb it. Yet, this effect might even be welcomed by autocratic systems from a Machiavellian perspective, especially when the state can gain legitimacy by seemingly effectively combating the increasing plague of witches. The post-colonial development in Cameroon may serve as an example. Here, the "unholy alliance" between the state and so-called witch-doctors, or féticheurs in French, consolidated and expanded the witchcraft craze. Accusations of witchcraft were interpreted and fought as a dangerous subversion of state power in general and of the development efforts 
of a bureaucratic centralized state in particular. Thus, the state recognized the féticheur as the main witness of the indictment (see Fisiy / Geschiere 1990: 147-54; Geschiere 1995: 264).

In some countries, like in Nigeria (Nupeland) or Zaire, the witch-doctor operates his business regularly and openly - including advertising with official "diplomas" and equipped with official credentials from the provincial administration (see Kohnert 1983; Duvieusart 1992: 468/69). The witch-doctor thus becomes a "profession", similar to that of an outpatient doctor, psychotherapist or village pharmacist. The demand comes from local village chiefs (see Kohnert 1983: 23-24 for Northern Nigeria; Drucker-Brown, 1993: 539 for Northern Ghana), who are sometimes even forced under the threat of state punishment to have their villages "cleaned" by witches (see Duvieusart 1992: 468), as well as by family-heads or individuals who are usually looking for somebody guilty for the disaster that happened to close relatives. Both witch-hunts and -punishments are also increasingly commercialized, similar to the traffic in indulgences in the European Middle Ages (see Elwert-Kretschmer, 1993; Kohnert 1983: 23-24; see Elwert's "Venality"-thesis ",see Elwert 1987).

The spread of witchcraft madness will not necessarily be stopped by the democratization process within the framework of the second wind of democratization in Sub Sahara Africa in the early 1990s. On the contrary, in Cameroon, for example, the political elite unintentionally uncovered a new source of witchcraft accusations with the democratic renewal process: While in Cameroon's centralized single-party system the state had banned or at least persecuted local non-governmental organizations until 1990, competing political elites now motivated their supporters to fight for votes and political loyalty in the country too. Especially when the party activists were successful and the villagers chose them as their legitimate representatives, the new local political leaders, the "évolués", inevitably submitted to the pattern of sanctions applicable in their home village. Therefore, the spectacular increase in prestige and wealth is invariably subject to witcheraft suspicion, especially if it is not shared with the members of the community based on the principle of mutual solidarity of the village community (see Geschiere 1996: 85.87-91). In this sense, "anti-social" denounces not only those who keep or consume their newly acquired wealth for themselves, but also the farmer or village trader who accumulates and invests his capital individually, or the official who "irrespectively of the person concerned", only assigns offices or provides services according to apparently objective performance criteria, and thus blatantly violates the traditional rules of the local clientele and patronage relationships, which require a priority consideration of members of the village community or the extended family.

Yet another way, but just as unintentionally, the ANC's political struggle against South Africa's apartheid regime in the homelands in the late 1980s and early 1990s led to a witch hunt of unprecedented proportions. Niehaus (1993: 518-27) shows in detailed case studies that young ANC activists - similar to the guerrillas in Zimbabwe's liberation struggle before (see Lan 1985: 167,170) - used witchcraft accusations and persecution as the key to political legitimacy, by profiling themselves in the "conquered" villages as committed and effective protective powers and pioneers against the seemingly omnipresent power of witchcraft. Unfortunately, the fighters against the apartheid-regime had thoroughly misunderstood the political instructions of the ANC, which had called for the eradication of "backward practices". Even after the ANC leadership called for the end of witch-persecution, many activists - like the rural population - were firmly convinced that their witch-hunt would promote the modernization and democratization process, which was apparently blocked by the backward practices of witches (see Evans, 1992: 56; Minnaar et al. 1991: 56). This witchhunt had a political dimension, namely the endorsement of the legitimacy of the young ANC activists, but - as Niehaus $(1993$; 1995) rightly emphasized - it was not a "political witch- 
hunt" in the narrower sense. In this, these witchcraft accusations differ fundamentally from the also politically motivated and instrumentalized allegations of ritual murder ( same region, which were aimed specifically at fighting the political opponent (see Minaar et al 1991: 53-55). The South African example refers to the fact that the construction of legitimacy by the state and the political recognition of witchcraft-belief have several dimensions that cannot be restricted to the structural and functional area. Witchcraft charges are not just a means to pursue a political purpose. The inner, existential dimension of coping with fear and self-discovery of individuals and political groups through witch accusations are politically at least as important as their conscious instrumentalization. Niehaus (1993) explains this in more detail using the example of the ANC activists.

\subsection{On the limits of the search of state legitimacy by supporting occult religions: The Example of the Kimbanguist Church and the vodun}

The existential dimension of the occult - introduced above - affects the legitimacy of the state not only directly and immediately in the form of the belief in magic and witchoraft, but also indirectly through the incorporation of occult elements into politically or state-sponsored African religions. A relatively well-documented example is the Kimbanguist church in Zaïre, one of the oldest and most important of the over 6,000 so-called "African independent churches". The Eglise de Jésus-Christ sur la terre par le Pro $\neg$ phète Simon Kimbangu (EJCSK) arose not only from the rejection of the complicity of the European Christian churches with the inhumane regime of the colonial state (see Körner 1995: 237) but also and above all as a reaction to the lack of understanding that Christian missionaries and churches showed regarding the need of the believers for protection from the supernatural evil powers. The constitutive element of Kimbanguism was the recognition of the existence of harmful magic and witchcraft, which established its relatively great attraction and following in comparison to the Western Christian churches ${ }^{6}$.

The EYCSK initially played a development-promoting, grass-roots democratic and emancipatory role. In the eyes of the colonial state, it was therefore rather suspicious and, like most autochthonous religious movements of that time, it was immediately subject to the suspicion of political subversion. In contrast, the close connection between Kimbanguism and the state brought about an urgently needed increase in legitimacy for the young Zairan nationstate. The unity of state and church leaders demonstrated in the eyes of the population the effective control of political power in the area of the profane as well as in the field of the occult.

However, the political ambivalence of such a legitimation of magically and religiously state rule soon became apparent: After the leadership of the Kimbanguists was completely taken over by the state from 1965 on, the Kimbanguist church degenerated in a kind of a "Constantinian shift" to an important pillar of the repressive state apparatus Mobutus (see Körner 1995: 238; Asch 1983). With Zaïre's second democratization process, which began in the early 1990s, and the death of the head of the EYCSK, Josèphe Diangienda, in July 1992,

\footnotetext{
6 "L'originalité du kimbanguisme réside dans sa reconnaissance de l'existence des kindoki (les esprits du mal, d. V.) invoqués par les ndoki (sorcier, d.V.), dans son recours au pouvoir (supérieur aux simbi) du Saint-Es $\neg$ prit descendu en Simon Kimbangu grâce aux dons transmis au chef spirituel et aux sacrificateurs (condisciples du Prophète) ... C'est ainsi que l'E.J.C.S.K. combat la sorcellerie ou le fétichisme, sans nier son existence, à la différence des Eglises missionaires occidentales." (Asch, 1983:219) - The same applies to the African church of Chrétiens Célestes, which is particularly widespread in West Africa, and the Rosicrucians.
} 
Kimbanguism was given the historic opportunity to contribute to establishing a new constitutional state on Zairian soil in opposition to the weakened Mobutu regime. It was hoped for that it could revive it's grassroots democratic traditions from the early colonial era -, similar to what the local Catholic Church had been doing since 1990 (see Körner 1995: 237). Yet, so far, Kimbanguism has apparently let this opportunity pass.

Religious practices - regardless of their orientation - always have an eminently political dimension in African countries as in many other Third World countries (see Bayart 1993: 15, 19-162). Recent efforts to upgrade African churches and religions, and to officially recognize them as a state-supporting element, are often accompanied by additional justifications. For example, they could constitute a starting point for anchoring an authentic African ethic that would be beneficial for the establishment of a democratically organized civil society. This especially applies to religions with strong occult elements such as the independent African churches in general and the West African vodun in particular. The latter has been fought not only by Christian missionaries and colonial masters but also by African leaders like Mathieu Kérékou, military dictator of socialist Benin (1972-1989), the cradle of vodun, as a "relic of feudalism" 7 .

However, efforts to rehabilitate the vodun, in order to promote democratic development, mostly strive to change the content and ethics of this belief system, away from the limitations of a secret cult towards a popular religion that is open to everyone. At least various new vodun cults in Bénin (e.g. alafia, atingali) are not tied to specific regions, ethnic groups or family associations (see Kadya Tall 1995: 235). In Bénin, these selective attempts had been encouraged by the official recognition of vodun under President Soglo in January 1996 as one of the country's major popular religions alongside Christianity and Islam.

The supporters of the development of "purified" African religious-political movements "from below" were able to refer to development models in other countries, presented at an international conference on the vodun in Ouidah (Bénin) in spring 1993, sponsored by Soglo (for the relevant literature see p Gbégnonvi 1993: 3.4).

In Haiti, for example, where the vodun had been imported together with African slaves, the religion became a refuge and alternative for the underprivileged in times of crisis, in contrast to the failed social development project of the elite ${ }^{8}$. The "revolution that arouses from the spirit of vodun" played a decisive role in the process of democratization after the fall of the Duvalier regime in 1986. This revolution had been supported by the vodun's social structure (see Rotberg 1976) and its socio-cultural environment, including politically oriented beat groups close to the people with their seditious songs (e.g. Boukman Eksperyans ). For the first time in Haiti's history, the vodun was publicly recognized as a popular religion by the new President Aristide and anchored in the constitution (Nicolas 1994: 111, 115).

However, Haiti's example shows at the same time the ambivalence of the political function of the vodun, which, like other religions and occult belief systems as well, can be used to

\footnotetext{
7 See Kadya Tall 1995: 196-99; Gbégnonvi 1993: 6. - The new governments of African states that were released into independence mostly took over the aversion of the colonial rulers against autochthonous African churches, at least when the latter also questioned the power of the new African government. Another example of this is the suppression by the Guinean state of Nino Vieira of the religious grass-roots njang-njang - movement, founded by Balante women at the end of the 1980s (see Kohnert 1996: 1350).

8 "Vodun is the most decentralized form of religions ... a belief system which 'pushes out from below'. Rather than being imposed from above, like most religi $\neg$ ons, it is 'bred and nurtured in the family, in the towns, and in the fields. It is common law' ... It is democratic, ordinary worshipers having direct access." (Rotberg 1976:345)
} 
legitimize any form of rule. Yet, in general, it has been used as an instrument of oppression or exploitation or as 'opium for the people' according to the Marxist aphorism (see Kohnert 1996: 1349). After his takeover in 1957, Haiti's President François Duvalier took vodun as an effective and dreaded means of terrorizing the population. In doing so, he assured himself of the active support of the majority of the vodun priests, whom he instrumentalized and even made some of them local leaders of his notorious group of thugs, the tonton macoutes (Nicolas 1994: 115; Rotberg 1976 : 362-365).

In Bénin too, the traditional commandments of vodun have primarily served to strengthen the traditional extended family and ethnic social structures from which they emerged (see Gbégnonvi 1993). Theoretically, the attempt to establish vodun as a state-supporting popular religion could be conveyed through the teaching of universal (rather conservative) basic ethical values (e.g. solidarity, honesty, courage, respect and loyalty) and through the desired institutional protection, also for the expansion of Bénin's civil society and the sustainable securing of state legitimacy.

In the event of a conflict between traditional local values of the community of believers vis-àvis higher-ranking national value systems (e.g. the fight against corruption and nepotism), however, the vodun encourages and legitimates (under otherwise identical conditions) the maintenance of traditional systems of rule, of patronage and of clientele networks with all the resulting negative consequences (see Elwert-Kretschmer 1995). As a religion based on fear, revenge and occultism, the vodun as a whole is probably more of an obstacle to democratization at the national level. This has been confirmed among others by Roger Gbégnonvi who vehemently rejects recent attempts at rehabilitation by the vodun ${ }^{9}$.

\section{On the instrumentalization of occult belief systems to support illegitimate rule}

Those who want to use occult belief systems to promote state legitimacy are embarking on a risky balancing act as shown above. It is all too easy, for those who want to trade in cheap legitimacy gains based on socio-cultural particularities in Africa, to run the risk of slipping into illegitimacy.

The use of magic and witchcraft to support illegitimate rule, i.e. to suppress and exploit the socially underprivileged can happen in a variety of ways. One example is the offensive use of belief in magic and witchcraft to actively combat the political opponent: this often happens simultaneously on several levels. They range from simple - more or less veiled - threats (e.g. threats by emirs in Northern Nigerian during the local government election campaign 1986 with an allusion to their assumed magical powers, according to the motto: "I can see who chooses my candidates and will act accordingly", see Kohnert 1983) and psychological warfare, psycho-terror, up to imprisonment in concentration camps for alleged 'witches' and finally the murder of opponents, e.g. by "black magic" (e.g. poisoning). Typically, under the conditions of the "African command state" (see Bierschenk, Elwert et al. 1993) and the

\footnotetext{
9 "Le vodun est force de terreur avant d'être force de mobilization, et c'est pourquoi après l'avoir servi et s'être servi de lui on peut encore se détacher de lui comme on s'éloinge d'un volcan dont on sait qu'il peut se réveiller à tout moment pour ravager sans rémission les terres qu'il a pourtant fertilisées. ... Quand le peuple, toutes tendances confondues, tient pour suspect le vodun, nous ne pouvons pas continuer à soutenir contre lui la théorie du vodun, ferment de liberté et d'épanouissement. Le vodun ne peut pas remplir cette fonction parce qu'il n'est pas transparent. ... parce qu'une telle prétention est aux antipodes de sa nature ... le vodun (est) ...inapte à toute réhabilitation dans sa forme d'hier parce qu'hier il a pactisé avec le crime (l'esclavage, d.V.). Il ne peut pas réhabilité dans sa forme d'aujourd'hui parce qu'aujourd'hui il refuse de reconnaître qu'il a pactisé hier avec le crime. ... Le vodun est disqualifié parce qu'il n'aime pas l'homme." (Gbégnonvi 1993:7-8).
} 
prevailing patronage system in most African countries, such sanctions threaten not only the direct political opponents but also their family members and followers, which renders already the mere threat extremely effective.

African autocrats such as Bokassa, Mobutu and Eyadéma seem to have used these instruments particularly virtuoso and unscrupulous (see Schatzberg 1993: 448-450; Nguza, 1982: 29-30, 63; Toulabor 1986: 124-131). The legitimation of these regimes by the occult was usually based on well-planned propaganda campaigns to strengthen the personal charism of the autocrats. Although the claim to legitimacy was thus bound to certain leaders who were portrayed as unique, it was not limited to this person but was inextricably linked to the clan and the regime of these leaders, i.e. the state apparatus that effectively guaranteed their rule, analogous to the fascist state of the Hitler regime.

Even if the cult of personality was usually orchestrated in advance and updated periodically, it would be wrong to assume that the instrumentalization of the occult was done in a purely Machiavellian manner without its own inner concern. Potentates like Eyadéma are themselves irretrievably entangled in the logic of magic and witchcraft and act accordingly in expanding their legitimacy-cult of personality, such as the "Eyadémaïsme" (see Toulabor 1986: 124-131, 133-229; Ellis 1993). In the following, this will be examined in more detail using the example of witch-hunts under the Eyadéma regime.

The public testimony during the Togolese Sovereign National Conference in August 1991 offered a unique opportunity to take a brief look behind the curtain of obscurity and murkiness that surrounded the occult "cleansing and punishment". Witness testimony from conference delegates in front of live TV cameras, backed up with concrete data and figures, gave the first glimpse of the full extent of Eyadéma's occult rule, which did not stop at his home village of Pya (central Togo, near Kara) and his own family. The delegate Toyi Assih, who, like the President belonged to the Kabyé ethnic group, testified, for example, to the deportation and murder by drowning and killing at least six named villagers for witchcraft in 1984 and 1985, and another eleven people from Pya were deported to a concentration camp in Mandouri (north Togo) designated for so-called witches, where they were also killed ${ }^{10}$.

Assih emphasized that, contrary to popular belief, Kabyés were in no way spared from the regime's terrorist measures. Some of the arbitrary executions took even place in the presence of the head of state in person. One of the above cases concerned the traditional chief and adoptive father of Eyadéma, another was murdered because he allegedly caused the death of the biological father of Eyadéma through witchcraft. Among those deported for witchcraft was a woman who had given birth to Eyadéma, etc. (see Ellis 1993: 472). The witness hearings during the National Conference made two things clear: First, the demonstration of occult power, rituals and symbols not only served the external bearing, as a means of securing legitimacy and despotic rule, but it was also used for private purposes. Second, the use of the occult to ritual murders to secure autocratic rule was not restricted to Eyadéma himself. Representatives of the Eyadéma regime were involved at all levels of state administration, from the interior minister to the simple Canton chief (see Ellis 1993 : 472). Thus, witchcraft accusations did not serve alone, and not even primarily, to secure personal power and rule, but to secure the dominance of a strategic group or faction of the country's political elite by all

\footnotetext{
${ }^{10}$ See the French daily Fraternité-Matin (Abidjan), "Togo - Conférence nationale", 9. August 1991, p. 24.
} 
means (occult and secular) that the system made available to the state apparatus tailored to their needs ${ }^{11}$.

The simple testimony of a cantonal chief was often sufficient to arrest the supposed witches and to keep them secretly as forced labourers on a farm under the surveillance of the traditional chiefs or in concentration camps (see Dovi 1992: 14). In this regard, the "Dossier Mandouri" presented for international attention at the National Conference in August 1991 by Robert Ahlonko Dovi, President of the Togolese National Human Rights Commission $(\mathrm{CNDH})$ was revealing. The visit, which took place the first time in November 1990 on requests of the Togolese human rights league and international Human Rights Organisations, in a "witch concentration camp" in Mandouri (north Togo, approx. $85 \mathrm{~km}$ east of Dapaong on the Béniner border). At the time of the investigation, there were still 41 persons present who had been accused of being witches or of committing witchcraft. They were held there indefinitely without official charges. Most of them (mostly belonging to the Kabyè ethnic group) had been deported by the traditional chiefs responsible for their respective home regions. The largest number (32) of concentration camp inmates in Mandouri came from the prefecture of Kozah (including 15 from Pya). Significantly, the existence of Togolese concentration camps has been known for a long time, at least according to rumours, even beyond the borders of Togo ${ }^{12}$.

In the context of the global East-West divide, in political circles that were benevolent to the Eyadéma regime, it was just not considered an option to break the "graveyard peace" in Togo, which until 1989 had been dubbed "Switzerland of Africa" by many politicians. Until 1989, the German federal government in general and its development aid in particular apparently had other standards for assessing the legitimacy of the Eyadéma regime than a few years later 13. In this respect, Togo is a good example of the fact that the survival of illegitimate regimes supported by occult claims to power, in Africa too, is often only possible with additional support and external attribution of "legitimacy" by foreign governments.

\footnotetext{
${ }^{11}$ The "secular" means of rule concerned in particular the military, a kind of Praetorian guard, which the Eyadéma regime had developed into one of the largest armies in the world per capita during the course of its almost thirty years of rule. However, this was only possible thanks to active 'development' assistance of the former colonial powers, France and Germany, over decades. The various state security services were committed to Eyadéma by ethnic- and family ties. An essential instrument of rule was also the mystically transfigured Rally of the Togolese People (RPT) with its sub-organizations (see also Toulabor 1986), which after five years of democratization that failed due to Eyadéma's role-back strategy of terror, regained its old power given the internal division of the opposition and manipulated elections in 1996.

${ }^{12}$ Already on June 27, 1985 there was an interpellation from the SPD (Dr. Diederich, Berlin) in the Bundestag, demanding whether it was true that with the help of German "equipment aid" (e.g. pioneer mission and police equipment) an access road to a "labour camp for alleged criminals without final judgment on work education" had been built near Kazaboua (Sotouba Prefecture). The Minister of State, Jürgen Möllemann (Foreign Affairs Department) of the Free Democratic Party, vehement rejected this accusation with regard to alleged typical African socio-cultural peculiarities, where there is not the same 'feeling of sovereignty', and moreover 'there are different opinions on certain concepts such as education and morality than ours.' He added that according to Togolese information, the camp under construction was only an "educational institution for young people who are difficult to educate". In fact, apparently "only" access-routes to the KZ-Kazaboua were built under the guidance of the German pioneers working as advisors and trainers in Togo (German Bundestag, minutes of the 10th parliamentary term, 149 session, Bonn, July 27, 1985, p. 11122 -25). - On the initiative of the CNDH, the concentration camp Mandouri was dissolved in spring 1991: "Ainsi depuis cette date, il n'existe plus de 'sorciers' à Mandouri en espérant qu'il n'existera plus ja $\neg$ mais de' sorcier '", it says in the Mandouri dossier (Dovi 1992: 15). Whether this hope proves to be viable remains to be seen, given the quasi-total recapture of old positions of power under the Eyadéma regime until 1996, not least, thanks to the active support of France.

${ }^{13}$ Due to the massive human rights violations of the Eyadéma regime, German development cooperation with Togo was officially largely suspended from February 1993.
} 


\section{Conclusions: Democracy in Africa cannot be induced by witchcraft}

At a time when the success of development aid in Africa is increasingly being questioned, new concepts and solutions are required. Even earlier technocratic-oriented donors, such as the World Bank, today emphasize the importance of the development of human capital, and moreover, they underline the importance of the social and political dimension (e.g. good governance, accountability, transparency) of the structural adjustment process, deemed to be indispensable. Linking innovations to socio-cultural conditions and endogenous resources is nowadays, not without good reason, a prerequisite for successful development programs ${ }^{14}$. This trend towards taking greater account of the socio-cultural dimension in development cooperation corresponds to a return to the partner's own local value systems. Because of the many failed attempts to democratize Africa's political systems since independence, it makes sense to "endogenize" the democratization aid for Africa (see Diaby-Pentzlin 1996). Too often, the inappropriate adaptation of formal-democratic Western democracy models has not resulted in more effective participation by the population, but only in an exchange of political elites.

There are, however, narrow limits to adapting political ruling systems to the socio-cultural local conditions in African countries. This applies in particular to attempts to solve one of the basic questions of development aid, the question of the legitimacy of the state's partners in development cooperation. According to tradition, in the eyes of most Africans, profane and occult power are inextricably linked. In contrast to a common view, the occult - as shown above - serves not only to support charismatic or traditional personal rule, but also legal state rule. However, if political adherence and the legal feeling of the population are so closely intervened with occult belief systems, then democratic aid based on socio-cultural conditions becomes a dangerous balancing act: it is therefore constantly necessary to check whether the sustainable promotion of participation- and emancipation-processes of the underprivileged by linking these processes to their systems of values and beliefs does not slip into counterproductive cultural relativism, which consciously or unconsciously supports repressive injustice regimes.

In principle, like many other belief systems (e.g. Christianity from the Crusades to the two world wars), belief in magic and witchcraft can serve to legitimize any rule, both despotic and legal democratic. Like other belief systems, African magic and witchcraft beliefs cannot be checked intersubjectively according to common scientific criteria, it is therefore largely beyond academic verification. The risk of abuse is in the case of occult belief systems especially large, among others because of the typical excessive "secrecy" surrounding them, the access restrictions (organization in secret societies; often discriminating against women) and the hierarchization of knowledge (according to different initiation levels etc.), which make the (sharing) sharing of knowledge more difficult. This is rather detrimental to the development of a democratic, self-determined society. On the other hand, a stronger disclosure and democratization of decision-making processes at all levels (from the government down to the village assembly) would be a necessary (but presumably not sufficient) precondition to curb the belief in magic and witchcraft. More transparency and a more open society based on the equal competition of ideas and political systems are the best guarantors for sustainable democratization.

\footnotetext{
${ }^{14}$ The BMZ's socio-cultural framework concept, which was adopted in 1992 as the basis for German state development cooperation, is an outstanding example.
} 


\section{References}

Ardener, Edwin (1970): Witchcraft, economics and the continuity of belief, in: Douglas, Mary (ed.), "Witchcraft confessions and accusations", Tavistock Publications, London, S. 141-60

Asch, Susan (1983): L'église du prophète Kimbangu - De ses origines à son rôle actuel au Zaïre. Paris

Awolalu, J. Omosade (1979): Yoruba beliefs and sacrificial rites. London

Bayart, Jean-François (Hrsg.)(1993): "Religion et modernité politique en Afrique noire - Dieu pour tous et chacun pour soi. Paris

Bierschenk, Thomas / Elwert, Georg / Kohnert, Dirk (1993): The long-term effects of development aid: empirical studies in rural West Africa", Economics (Tübingen), vol. 47, No. 1, S. 83-111

Chavunduka, G. L. (1980): Witchcraft and the law in Zimbabwe. Zambwezia (Harare), vol. 8, No. 2, S. 129-147

Chukkol, Kharisu Sufiyan (1981): Supernatural beliefs and the criminal law in Nigeria - A critical appraisal. Zaria

Comaroff, Jean / Comaroff, John (Hrsg.) (1993): Modernity and its malcontents: Ritual and power in postcolonial Africa. Chicago

Diaby-Pentzlin, Friederike (1996): Rechtsprojekte auf dem Weg zur Endogenisierung. Entwicklung und Zusammenarbeit $(\mathrm{E}+\mathrm{Z})$, Vol. 37, Nr.11, S. 310-11

Douglas, Mary (Hrsg.) (1970): Witchcraft accusations and confessions. London

Dovi, Ahlonko (1992): Dossier Mandouri. in: Les Echos, Magazine d'information de la Commission Nationale des Droits de l'Homme (CNDH), No. Special, S. 14-17

Drucker-Brown, Susan (1993): Mamprusi witchcraft, subversion and changing gender relations. in: Africa (London), vol. 64, No. 4, S. 531-549

Duvieusart, Léopold s.j.(1992): Cas de recherche de sorcellerie en milieu rural au Zaïre. Suggestions sur la conduite à tenir par les autorités de l'Etat. in: Zaïre-Afrique (Kinshasa), S. 457-471

Elias, Norbert (1976): Über den Prozeß der Zivilisation - Soziogenetische und psychogenetische Untersuchungen. vol. 2 Wandlungen der Gesellschaft: Entwurf zu einer Theorie der Zivilisation. Frankfurt/M.

Ellis, Stephen (1993): Rumour and power in Togo. in: Africa (London), vol. 63, No.4, S. 462-476

Elwert, Georg (1987): Ausdehnung der Käuflichkeit und Einbettung der Wirtschaft. in: Klaus Heinemann (Hrsg.): "Soziologie wirtschaftlichen Handelns". Sonderheft Nr. 28 der Kölner Zeitschrift für Soziologie und Sozialpsychologie, S. 300-321.

Elwert-Kretschmer, Karola (1995): Vodun et contrôle social au village. in: Politique Africaine, vol. 59, S. 102119

Engel, Ulf / Hofmeier, Rolf / Kohnert, Dirk / Mehler, Andreas (Hrsg.)(1995): Wahlbeobachtung in Afrika. Arbeiten aus dem Institut für Afrika-Kunde, No. 90, Hamburg

Evans, Jeremy (1991): Muti murders - Ritual responses to stress. in: Indicator SA, vol. 8, No. 4, S. 46-48

Evans, Jeremy (1992): On brule bien les sorcières - Les meurtres muti et leur repression. in: Politique Africaine, vol. 48 , S. $47-57$

Evans-Pritchard, E.E. (1937): Witchcraft, Oracles and Magic among the Azande. Oxford

Fisiy, C. / Geschiere, P. (1990): Judges and witches, or how is the state to deal with witchcraft ? in: Cahiers d'Etudes Africaines, vol. 118, S. 135-156 
Fisiy, Cyprian / Geschiere, Peter (1991): Sorcery, witchcraft and accumulation: regional variations in south and west Cameroon. in: Critique of Anthropology, vol. 11, No. 3, S. 251-278

Fisiy, Cyprian F. (1990): Le monopol juridictionnel de l'Etat et le règlement des affaires de sorcellerie au Cameroun. in: Politique africaine, vol. 40, S. 60-71

Gbégnonvi, Roger (1993): Le vodun disqualifié. mimeo, Cotonou

Geschiere, Peter (1988): Sorcellerie et modes populaires d'action politique chez les Maka (Cameroun). in: Bogumil Jewsjewicki (Hrsg.): Savoire, pratiques populaires en Afrique. Paris

Geschiere, Peter (1995): Sorcellerie et politique en Afrique: La viande des autres. Paris

Geschiere, Peter (1996): Sorcellerie et politique: les pièges du rapport élite-village. in: Politique Africaine, vol. 63, S. $82-96$

Geschiere, Peter / Fisiy, Cyprian (1994): Domesticating personal violence: witchcraft, courts and confessions in Cameroon. in: Africa, vol. 64, No. 3, S. 323-341

Geschiere, Peter / Konings, Peter (Hrsg.) (1993): Les itinéraires de l'accumulation au Cameroun. Paris

Gluckman, Max (1944): The logic of African science and witchcraft. in: Marwick (Hrsg.), 1975, S. 321 -331

Kadya Tall, Emmanuelle (1995): De la démocratie et des cultes voduns au Bénin. in: Cahiers d'Etudes Africaines, vol. 36, No. 1, S. 195-208

Körner, Peter (1995): Die Transformation der kimbanguistischen Kirche im Prozeß des Wandels der Gesellschaftsverfassung in Zaïre. in: Pitschas, Rainer / Sülzer, Rolf (Hrsg.): Neuer Institutionalismus in der Entwicklungspolitik. Berlin, S. 235-53

Kohnert, Dirk (1983): Indicators of social and political conflict in African societies: on the articulation of witchcraft among the Nupe, Northern Nigeria. Working Paper No. 32, Forschungsschwerpunkt Entwicklungssoziologie, Universität Bielefeld

Kohnert, Dirk (1988): Socialism without liberation - Land reclamation projects in Guinea-Bissau. in: Sociologia Ruralis, No. 2/3, S. 161-175

Kohnert, Dirk (1996): Magic and witchcraft: implications for democratization and poverty-alleviating aid in Africa. in: World Development, vol. 24, No. 8, S. 1347-1355

Macfarlane, A.D.J. (1970): Witcheraft and conflict. in: Macfarlane, A.D.J.: Witcheraft in Tudor and Stuart England. London, Chap. 15. reprinted in: Marwick, Max (Hrsg.)(1975), "Witchcraft and Sorcery. Selected Readings". Harmondsworth, S. 296-304

Macfarlane, A.D.J. (1970a): Definitions of witchcraft. in: Macfarlane, A.D.J.: Witchcraft in Tudor and Stuart England. London, App. 2; reprinted in: Marwick, Max (ed.)(1975): Witchcraft and Sorcery. Selected Readings. Harmondsworth, S. 41-44

Marwick, Max (1964): Witchcraft as a social strain-gauge. in: Australian Journal of Sociologie, vol. 26, S. 26368; reprint in: Marwick, Max (Hrsg.)(1975): Witchcraft and Sorcery. Selected Readings. Harmondsworth, S. 280-295

Marwick, Max (Hrsg.) (1975): Witchcraft and Sorcery. Selected Readings. Harmondsworth

Mayrargue, Cédric (1995): Le religieux et les législatives de mars 1995 au Bénin. in: Politique Africaine, vol. 58, S. $158-162$

Minnaar, Anthony / Offringa, Dirkie / Payze, Catharine (1991): The witches of Venda: Politics in magic potions. in: Indicator SA, vol 9, No 1, S. 53-56

Multhaupt, Tamara (1990): Hexerei und Antihexerei in Afrika. München 
Nadel, Siegfried F. (1952): Witchcraft in four African Societies. in: The American Anthropologist, vol. 54, S. 18-29; reprinted in: Marwick, Max (Hrsg.)(1975): Witchcraft and Sorcery. Selected Readings. Harmondsworth, S. 264-279

Nadel, Siegfried F. (1954): Nupe Religion. London; reprint 1970

Nguza, Karl I Bond (1982): Mobutu - ou l'incarnation du mal Zaïrois. London

Nicolas, Alrich (1994): Die kulturpolitischen Wurzeln Haitis. Vaudou als Institution für ein neues Gesellschaftsprojekt. in: Rieger, Gerhard (Hrsg.): Die Karibik zwischen Souveränität und Abhängigkeit. in: Blätter des IZ3W, Freiburg, Januar 1994, S. 111-116

Niehaus, Isak A., (1993): Witch-hunting and political legitimacy: Continuity and change in Green Valley, Lebowa, 1930-91. in: Africa, vol. 63, No. 4, S. 498-530

Niehaus, Isak A., (1995): Witches of the Transvaal Lowveld and their familiars: Conceptions of Duality, power and desire. in: Cahiers d'Etudes africaines, vol. 138-139, vo. 35-2-3, S. 513-540

Nieuwaal, E.A.B. van Rouveroy van (1990): Sorcellerie et justice coutumière dans une societé togolaise. in: Journal of Legal Pluralism and Unofficial Law, vol. 29, S. 137-162

Nogueira, Amadeu (1947): O 'Irâ' na Circumscriçâo de S. Domingos. Bolletim Cultural da Guiné Portuguesa. (Bissau/Lisbon), No. 7, S. 711-716

Odinkalu, Anselm Chidi (1992): Justice denied - The Area Court system in the Northern States of Nigeria. Civil Liberties Organisation, Ibadan

Ralushai, N.V. / Masingi, M.G. / Madiba, D.M.M. / Van den Heever, J.A. / Mathiba, T.J. / Mphaphuli, M.E. / Mokwena, M.W. / Vele Ndou, P.N. / Matabane, D. (1996): Report of the commission of inquiry into witchcraft violence and ritual murders in the Northern Province of the Republic of South Africa. Report submitted to "His excellency the honourable member of the executive council for savety and security, Northern Province, Advocate Seth Nthai". o.O., unveröffentlicht, 274 S., plus Annex

Raynal, Maryse (1994): Justice traditonelle, justice moderne - Le devin, le juge et le sorcier. Paris

Reining, Conrad C. (1966): The Zande Scheme: an anthropological case study of economic development in Africa. Evanston, Illinois

Renteln, A.D. (1987): Culture and culpability: a study of contrast. in: Beverly Hills Bar Association Journal, Winter $1987 / 88$, S. $17-27$

Rotberg, Robert I. (1976): Vodun and the politics of Haiti. in: Kilson, M. / Rotberg, R. (Hrsg.): The African Diaspora. Harvard, S. 342-365

Schatzberg, Michael G. (1993): Power, legitimacy and 'Democratization' in Africa. in: Africa, vol. 63, No. 4, S. 445-461

Sulikowski, Ulrike (1993): 'Sie geben eine Party für die Götter und die Götter kommen'. Überlegungen zu Vodun, Besessenheitskulten und dem Diskurs über Afrika. in: Fillitz, Thomas et al. (Hrsg.). Kultur, Identität und Macht. Frankfurt/M.

Toulabor, Comi M. (1986): Le Togo sous Eyadéma. Paris

Tseayo, J. I. (1975): Conflict and incorporation in Nigeria. Zaria

Turner, V.W. (1964): Witchcraft and sorcery: taxonomy versus dynamics. in: Africa, vo. 34, No. 4, S. 319-24

Welch, Claude Jr. (1992): Human rights charter. in: West Africa, Nov. 16-22, 1992, S. 1952

Wilson, K.B. (1992): Cults of violence and counter-violence in Mozambique. in: Journal of Southern African Studies, vol. 18, No. 3, S. 527-582

Wonyu, Emmanuel (1992): Un support juridique pour la démocratie en Afrique: La charte Africaine des Droits de l'homme et des Peuples. in: Afrique 2000, Febr. 1992, S. 29-45 